\section{Implications of ecotourism development in protected areas: a study from Rema-Kalenga Wildlife Sanctuary, Bangladesh}

\author{
Rana MP (1), Sohel MSI ${ }^{(1)}$, Mukul SA ${ }^{(2)}$, Chowdhury MSH ${ }^{(3)}$, Akhter S (1), \\ Koike $M^{(3)}$
}

This article is based on visitors profile study of protected area based tourist spots of Rema-Kalenga Wildlife Sanctuary (RKWS), Bangladesh to ascertain the potential of ecotourism. Study findings shows that $69 \%$ male constitute the visitors group while the maximum number of visitors was found in the age of below 30 years. Most of the visitors were literate and among them $43 \%$ visitors were student. Most $(53 \%)$ of visitors preferred to get recreation in holidays as they were employed. Visitors were highly preferred to come with friends group. About $92 \%$ respondents showed positive mind to come here in future while $89 \%$ respondents view that park has tourism potential. Most of the respondents reported the presence of wildlife $(48 \%)$ most notable followed by plant diversity and tribal community as recreational. From $\chi^{2}$ test it is found that highly significance association present between tourism potentiality of the wildlife sanctuary and some demographic variable like income of tourists $\left(\chi^{2}=\right.$ $49.138, \mathrm{p}<0.000)$, visiting pattern $\left(\chi^{2}=19.344, \mathrm{p}<0.000\right)$, education of tourists $\left(\chi^{2}=50.226, \mathrm{p}<0.000\right)$, travelling distance $\left(\mathrm{Km}-\chi^{2}=11.427, \mathrm{p}<0.022\right)$, duration of staying $\left(\chi^{2}=12.867, p<0.002\right)$, frequency of visit $\left(\chi^{2}=8.456, p<\right.$ $0.015)$, visiting time $\left(\chi^{2}=6.530, p<0.011\right)$, problem in the study area $\left(\chi^{2}=\right.$ $14.962, p<0.021)$, occupation of tourists $\left(\chi^{2}=8.848, p<0.031\right)$. If the problems addressed by the visitors were solved, RKWS would be a bright place of eco-tourism in Bangladesh.

Keywords: Ecotourism, Protected area, Tourism potential, Visitors, Bangladesh

\section{Introduction}

Worldwide, many countries and regions rich in biodiversity and poor in economy have been vigorously promoting ecotourism as a conservation tool in their protected areas (PAs) since the 1990s (He et al. 2008). PAs now cover more than $12 \%$ of the world's land area. These PAs are on the front line in the campaign to conserve biodiversity as well as to promote eco-tourism on the planet Earth (Chape et al. 2003, Hales 1989). Tourism use of PAs basically involves the travel for the discovery and learning about wild environments. The importance of nature in attracting tourists is significant and stated that nature and cultural heritage represent a competitive advantage for many areas, for different kinds of protected areas (Williams 1992), a chance to see wildlife and undisturbed nature is rated as very important reason for visits to PAs (Goodwin 1996). PAs are becoming more popular destinations for wildlife tourists of national and international origin. Besides this, economic benefits from tourism are observed in different PAs. Protected area based eco-tourism that can give rise to economic benefits to local communities as well as to the nation (Hales 1989, Goodwin 1996, Wells et al. 1992, Western \& Wright 1994, Hannah 1992, Ghimire \& Pimbert 1997, GOI 1994, Fiallo \& Jacabson 1995, Ite 1996, Mehta \& Kellert 1998, Rao 1996, Lindberg \& Enriquez 1994, Walpole \& Goodwin 2000, Walpole et al. 2001). Nature or forest based tourism is a key category of eco-tourism, one of the fastest growing sectors of the world (Landell-Mills \& Porras 2002). However in Bangladesh this promising sector is poorly utilized. From a source it has been found that, less than 10000 foreign visitors entered in 1992, domestic tourism on the other hand appears to be a strongly flourishing sector of the market (Vantomme et al. 2002).

Protected areas have played significant roles as tourist attractions in many countries
(1) Department of Forestry and

Environmental Science, School of Agriculture and Mineral Sciences, Shahjalal University of Science and Technology, Sylhet- 3114 (Bangladesh); (2) Institutute of International Forestry and Forest Products, Dresden University of Technology, 01735 Tharandt (Germany); (3) Forest Policy Laboratory, Department of Forest Science, Faculty of Agriculture, Shinshu University, 8304 Minamiminowa-Mura, 399-4598 Nagano-Ken (Japan)

(a) M. Parvez Rana (parvez_200207@yahoo.com)

Received: Aug 07, 2009 - Accepted: Oct 28, 2009

Citation: Rana MP, Sohel MSI, Mukul SA, Chowdhury MSH, Akhter S, Koike M, 2010. Implications of ecotourism development in protected area: a study from Rema-Kalenga Wildlife Sanctuary, Bangladesh. iForest 3: 23-29 [online: 2010-01-22] URL:

http://www.sisef.it/iforest/show.php? id $=520$

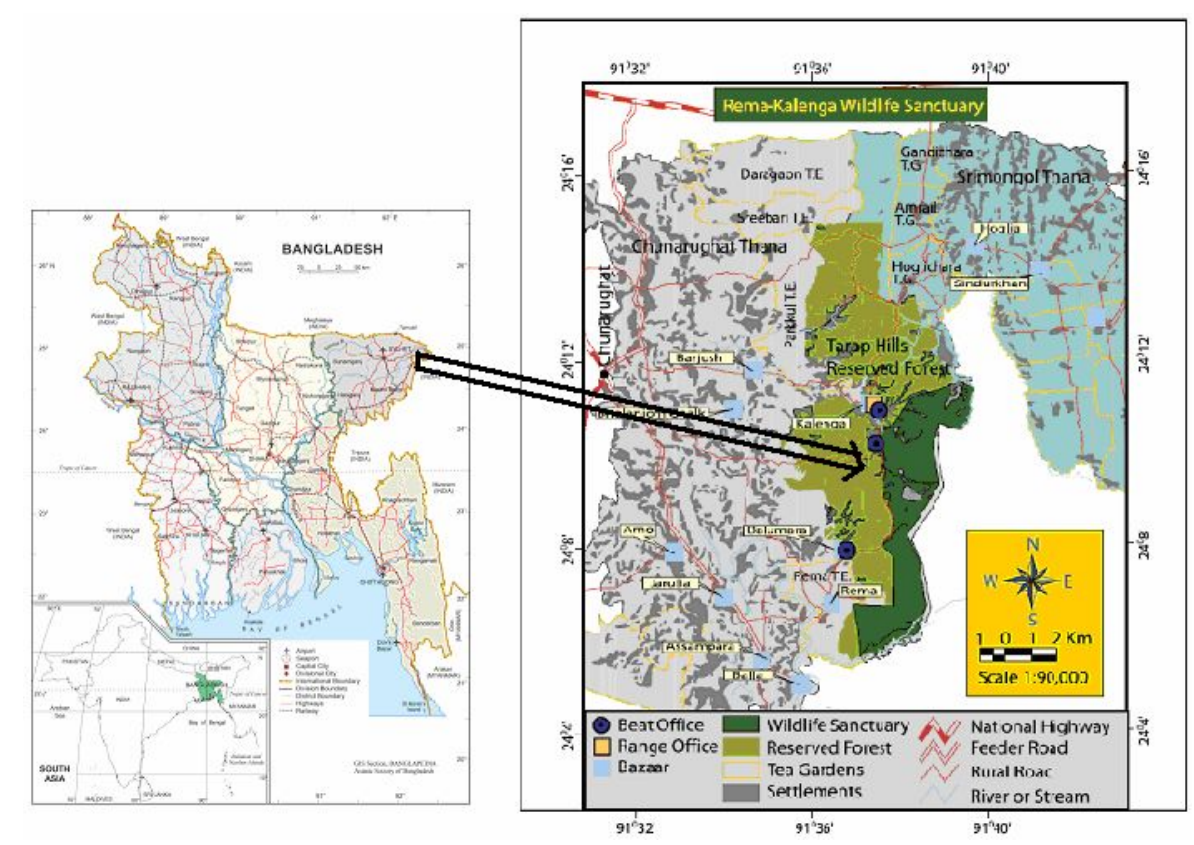

Fig. 1 - Location Map of RKWS. 
Tab. 1 - Description of the Rema-Kalenga Wildlife Sanctuary (RKWS - source: NACOM 2003, Uddin 2002).

Items

Forest type

Location

Area

Forest type

Bio-ecological Zone

Climate

Topographic

characters

Floral diversity

Faunal diversity

Important attractive features

No. of villages

No. of households

Average household

size (Persons)

since their establishment (Butler \& Boyd 2000). PAs with their landscapes, flora and fauna as well as their cultural elements form attractions for tourists (Ceballos-Lascurain 1993). Another thing is that eco-tourism continues to become a management strategy for protected areas. There are numerous opportunities for ecotourism in protected areas. Such opportunities are revenue generation (i.e., user fees, entranced fees and donations), employment creation, justification for protected areas, healthier economies, environmental education, and improved conservation efforts (Borrie et al. 1998, Drumm $\&$ Moore 2005). Presently, there are 19 notified protected areas (i.e., 11 national parks, seven wildlife sanctuaries and one game re-

serve) in Bangladesh (NSP 2006). Compared to other regions of the world, this figure is still very poor. The PAs of Bangladesh cover nearly $1.7 \%$ of the total landmass of the country, which is the second lowest per capita area under PAs in any country (Sharma et al. 2005). As the tourism industry is quickly becoming the most profitable industry in developing countries, Government of Bangladesh should give emphasis to increase protected areas for ecotourism development. As PAs has become a new tool to promote environmentally and culturally friendly tourism, but still now a little reliable or published information is available regarding the tourism potentialities of PAs of Bangladesh. Taking this view a head the

Tab. 2 - Visiting time, frequency of visit and duration of staying the visitors.

\begin{tabular}{|c|c|c|c|c|c|c|c|c|}
\hline \multirow[b]{2}{*}{ Category } & \multicolumn{2}{|c|}{ Visiting time } & \multicolumn{3}{|c|}{ Frequency of visit } & \multicolumn{3}{|c|}{ Duration of staying (h) } \\
\hline & $\begin{array}{c}\text { Holy- } \\
\text { days }\end{array}$ & $\begin{array}{c}\text { Free time } \\
\text { without } \\
\text { holydays }\end{array}$ & Once & Twice & $\begin{array}{c}\text { More } \\
\text { than twice }\end{array}$ & $<2$ & $2-5$ & $>5$ \\
\hline Number & 79 & 71 & 67 & 63 & 20 & 20 & 116 & 14 \\
\hline Percentage & 52.7 & 47.3 & 44.7 & 42 & 13.3 & 13.3 & 77.3 & 9.3 \\
\hline
\end{tabular}

present study was conducted in RemaKalenga Wildlife Sanctuary of Bangladesh to assess the recreation potential as a protected area, which will help the planner to provide an effective plan for its management and improvement. Also influence to increase protected areas for ecotourism development in Bangladesh.

\section{Methodology}

Site profile

Rema-Kalenga Wildlife Sanctuary (RKWS) is located approximately $130 \mathrm{~km}$ east-northeast of Dhaka and $80 \mathrm{~km}$ southsoutheast of Sylhet in Chunarughat Thana, a sub-district of Habiganj District, Sylhet. The sanctuary is bounded by Tripura State (India) to the south and east, and Kalenga Forest Range to the north and west. Geographically, the area lies between $24^{\circ} 06^{\prime}$ $24^{\circ} 14^{\prime} \mathrm{N}$ latitude and $91^{\circ} 34^{\prime}-91^{\circ} 41^{\prime} \mathrm{E}$ longitude (Fig. 1). The area falls under the Sylhet Hills zones (Nishat et al. 2002), and the administrative area is known as the RemaKalenga Forest Range. Table one describes the main features of the Rema-Kalenga Wildlife Sanctuary.

\section{Data collection and analysis}

To collect data and information, an opinion pull was conducted in the study areas. This was because most of recreation seekers were willing to pass their spare time in these ecotourism spots. Visitor's survey method was conducted for valuation of outdoor recreation. A total of 150 respondents were interviewed representing different socio-economic and occupational groups. The selection of respondents was done randomly to avoid serious biasness. The respondents were interviewed with a semi-structured questionnaires designed for this purpose. The aim of survey was to gather information related to demography of visitors as the major stakeholder (e.g., age, education and occupation), visits to the park (e.g., frequency, season, time, purpose, form of visit, willingness to further visit), tourism potential of the park and problems faced by the visitors during visits. Descriptive statistics were derived to summarise the property of the dataset, while analytical methods (correlation and chi-squared test) were used to analyse the data and test for differences (at 95\% level of significance). Analysis was conducted using SPSS ver 10.0 (Statistical Package for the Social Sciences). Here, chi-squared test explains the relationship between tourism potential with other demographic variable.

\section{Results}

Demographic characteristics of visitors

The total visitors of the surveyed area were 150 , of which $103(68.7 \%)$ were male and the 
rest $47(31.3 \%)$ were female. Among the visitors, $60 \%$ male said that the RKWS is tourism potential (Tab. 3). While $2.66 \%$ females view were negative. Majority of the visitors belong to younger groups ( $<30$ years), which is about $84 \%$. Older age groups ( $>30$ years) represents only $16 \%$ (Fig. 2).

Study shows that most $(89.7 \%)$ of the visitors are literate. Among the visitors, education status of $17.3 \%$ visitors are the primary and secondary level and $28.7 \%$ are the higher secondary level (Fig. 3). Among the respondents, above higher secondary (Graduate, $\mathrm{PhD}$ ) level visitors (42.66\%) opined that the site is tourism potential (Tab. $3)$.

Findings revealed that $78.7 \%$ visitors are employed. Students represent the highest number of visitors (42.7\% - Fig. 4). Among the different occupational group $41.33 \%$ student's attitude was positive about the RKWS that is the recreation potential (Tab. 3). Most of the visitors in the study area are visiting in a group with friends ( $42 \%)$ followed by family groups $(25.3 \%)$. Couple category represents the lowest number of visitors $(12.7 \%$ -

Fig. 5). Maximum $40.66 \%$ group of friends told that the RKWS has tourism potential (Tab. 3).

\section{Economics of the visitors}

Maximum visitors (56.7\%) are come from medium family followed by rich family (24\%). Among the different income group highest $(54.66 \%)$ visitors of medium family opined that the site is recreation potential (Tab. 3). Most of the visitors (26.7\%) spend $<200 \mathrm{Tk}$ followed by $500-800 \mathrm{Tk}(24 \%)$, 800-1100 TK (20.7\%) and 200-500 Tk $(16.7 \%)$ to visit the study area (Tk means Taka, Bangladeshi currency, 1US\$ $=70 \mathrm{Tk}$ ). Most of the visitor $(21.33 \%)$ those who spend $<200 \mathrm{Tk}$ and $500-800 \mathrm{Tk}$ told that RKWS is a tourism potential site respectively (Tab. 3).

Duration, visiting time, frequency of visit and traveling distance

Study revealed that $52.7 \%$ visitors preferred to pass their spare time during holidays and the remaining $47.3 \%$ visitors desired to enjoy the RKWS other than holidays (Tab. 2). 50\% visitors those pass their time during holidays told that the RKWS is recreation potential (Tab. 3). It is found that most of the visitors $(44.7 \%)$ visited RKWS for the first time followed by for the second time $(42 \%)$ and more than twice (13.3\%). 39.33\% of the visitors those who came second time told that the site is tourism potential. The study indicate that most of the visitors (77.3\%) stay at the RKWS for (2-5) h followed by less than $2 \mathrm{~h}(13.3 \%)$ and more than $5 \mathrm{~h}(9.3 \%)$. Among the respondents those spent $(2-5) \mathrm{h}, 71.33 \%$ told that the RKWS is recreation potential (Tab. 3). Fin-
Tab. 3 - Chi-square test of relationship between demographic variable and potentiality of park $(\mathrm{n}=150)$.

\begin{tabular}{|c|c|c|c|c|c|}
\hline \multirow[t]{2}{*}{ Parameter } & \multirow[t]{2}{*}{ Variable } & \multicolumn{2}{|c|}{$\begin{array}{l}\text { Potentiality of } \\
\text { the park (\%) }\end{array}$} & \multirow[t]{2}{*}{$\chi^{2}$} & \multirow{2}{*}{$\mathbf{p}$} \\
\hline & & Yes & No & & \\
\hline Age of the & $<20$ & 10.66 & 2.66 & 2.811 & 0.422 \\
\hline \multirow[t]{3}{*}{ tourists $(Y r)}$. & $20-25$ & 39.33 & 4.66 & & \\
\hline & $25-30$ & 23.33 & 3.33 & & \\
\hline & $30+$ & 15.33 & 0.66 & & \\
\hline Traveling & $<25$ & 20.66 & - & 11.427 & 0.022 \\
\hline \multirow[t]{4}{*}{ distance $(K m)$} & $25-50$ & 15.33 & 5.33 & & \\
\hline & $50-75$ & 20.66 & 3.33 & & \\
\hline & $75-100$ & 10.66 & 0.66 & & \\
\hline & $100+$ & 21.33 & 2.00 & & \\
\hline \multirow{5}{*}{$\begin{array}{l}\text { Traveling Cost } \\
\text { (Tk.) }\end{array}$} & $<200$ & 21.33 & 5.33 & 5.653 & 0.227 \\
\hline & $200-500$ & 15.33 & 1.33 & & \\
\hline & $500-800$ & 21.33 & 2.66 & & \\
\hline & $800-1100$ & 18.66 & 2.00 & & \\
\hline & $1100+$ & 12.00 & - & & \\
\hline \multirow{3}{*}{$\begin{array}{l}\text { Duration of } \\
\text { staying }\end{array}$} & $<2$ & 8.66 & 4.66 & 12.867 & 0.002 \\
\hline & $2-5$ & 71.33 & 6.00 & & \\
\hline & $5>$ & 8.66 & 0.66 & & \\
\hline \multirow{3}{*}{$\begin{array}{l}\text { Frequency } \\
\text { of visit }\end{array}$} & First time & 36.00 & 8.66 & 8.456 & 0.015 \\
\hline & Second time & 39.33 & 2.66 & & \\
\hline & More than second time & 13.33 & - & & \\
\hline \multirow[t]{2}{*}{ Visiting time } & Holiday & 50.00 & 2.66 & 6.530 & 0.011 \\
\hline & Without holiday & 38.66 & 8.66 & & \\
\hline \multirow{3}{*}{$\begin{array}{l}\text { Income of } \\
\text { tourists }\end{array}$} & $<8000$ (Low income group) & 10.00 & 9.33 & 49.138 & 0.000 \\
\hline & $8000-15000$ (Medium income group) & 54.66 & 2.00 & & \\
\hline & $>15000$ (Rich group) & 24.00 & - & & \\
\hline \multirow[t]{4}{*}{ Visiting pattern } & Individual & 13.33 & 6.66 & 19.344 & 0.000 \\
\hline & Group of friends & 40.66 & 1.33 & & \\
\hline & Family & 22.66 & 2.66 & & \\
\hline & Couple & 12.00 & 0.66 & & \\
\hline \multirow{7}{*}{$\begin{array}{l}\text { Problem in the } \\
\text { study area }\end{array}$} & Sanitation & 18.00 & 2.66 & 14.962 & 0.021 \\
\hline & Drinking water & 14.00 & 0.66 & & \\
\hline & Security & 11.33 & - & & \\
\hline & Communication & 12.00 & 2.00 & & \\
\hline & Accommodation & 16.66 & - & & \\
\hline & Food & 12.66 & 4.00 & & \\
\hline & Guiding & 4.00 & 2.00 & & \\
\hline \multirow{4}{*}{$\begin{array}{l}\text { Occupation of } \\
\text { tourists }\end{array}$} & Service & 14.66 & 2.00 & 8.848 & 0.031 \\
\hline & Business & 16.00 & 3.33 & & \\
\hline & Student & 41.33 & 1.33 & & \\
\hline & Un-employed & 16.66 & 4.66 & & \\
\hline \multirow{4}{*}{$\begin{array}{l}\text { Education of } \\
\text { tourists }\end{array}$} & Illiterate & 4.00 & 6.66 & 50.226 & 0.000 \\
\hline & Primary \& Secondary & 14.66 & 2.66 & & \\
\hline & Higher Secondary & 27.33 & 1.33 & & \\
\hline & Above & 42.66 & 0.66 & & \\
\hline \multirow[t]{2}{*}{ Sex of tourists } & Male & 60.00 & 8.66 & 0.543 & 0.461 \\
\hline & Female & 28.66 & 2.66 & & \\
\hline
\end{tabular}

dings showed that $24 \%$ visitors come from a from $100+\mathrm{Km}$ distances told that the site distances range (50-75) $\mathrm{Km}$ followed by has ecotourism potentiality (Tab. 3). $100+\mathrm{Km}$ distances $(23.3 \%),<25 \mathrm{Km}$ distances (20.7\%), (25-50) $\mathrm{Km}$ distances Problems identified by the visitors $(20.7 \%)$ and $75-100 \mathrm{Km}$ distances $(11.3 \%$ - According to the visitors, the remarkable Fig. 6). Highest $21.33 \%$ visitors who came problems are insufficient toilets, accommo- 
Fig. 2 - Age group of the visitors.

Fig. 3 - Educational status of the visitors.

Fig. 4 - Occupational status of the visitors.

Fig. 5 - Visiting pattern of respondents in RKWS. 
Fig. 6 - Travelling distance of the visitors.

Fig. 7 - Problems faced by the visitors.

Fig. 8 - Attractive recreation component of RKWS.
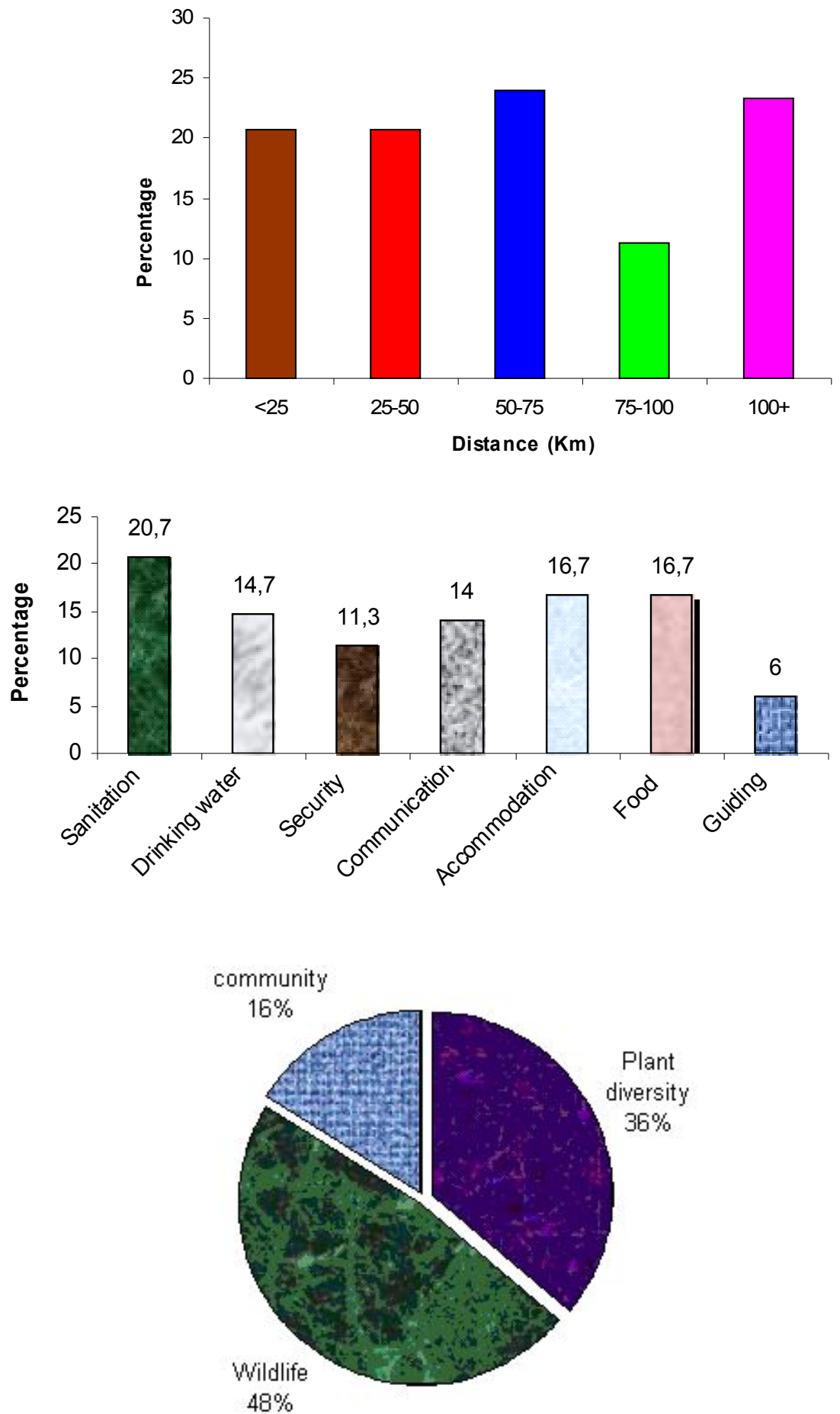

dation problem, non-availability of food, non-availability of drinking water, and lack of proper communication facilities, lack of sufficient security and guiding (Fig. 7).

\section{Tourism potential}

Of the surveyed respondents, $88.7 \%$ were of the view that their visit experience at RKWS was recreational and only $11.3 \%$ respondents stated it was not so. The respondents, to whom visit to the RKWS appeared recreational, were asked specific question on what component provided them recreation most. In response to it, most of the respondents reported the presence of wildlife (48\%) most notable followed by plant diversity $(36 \%)$ and tribal community (16\%) as recreational (Fig. 8).

Another specific question was asked whether the respondents would like to make recurrent visit to the site in future. A high proportion of respondents (92\%), after the visit experience at RKWS expressed their willingness to make further visits while only
$8 \%$ respondents denied coming again.

Relationship between demographic variable and tourism potentiality of the park

From chi-square test it is found that highly significance association present between tourism potentiality of the wildlife sanctuary and some demographic variable like income of tourists (chi-square $=49.138, p<0.000$ ), visiting pattern (chi-square $=19.344$, $p<0.000$ ), education of tourists (chi-square 
$=50.226, p<0.000)$, travelling distance $(\mathrm{Km}-$ chi-square $=11.427, p<0.022)$, duration of staying (chi-square $=12.867$, $p<0.002$ ), frequency of visit (chi-square $=$ $8.456, p<0.015)$, visiting time (chi-square $=$ $6.530, p<0.011$ ), problem in the study area (chi-square $=14.962, p<0.021)$, occupation of tourists (chi-square $=8.848, p<0.031$ Tab. 3). But on the other hand, there is no significant association found among sex, age and travelling cost of the tourist with tourism potentiality of the wildlife sanctuary.

\section{Discussion}

Establishment of protected areas (PAs) has been the most widely accepted means of biodiversity conservation so far, supported by national and international agencies (Hales 1989, Sekhar 2003, Walpole et al. 2001). Tourism use of PAs basically involves the travel for the discovery and learning about wild environments. Tourism is viewed in many industrial nations as an environmentally friendly way to revitalize distressed rural communities and economies. A similar view is gaining momentum in developing countries like Bangladesh where PAs are becoming more popular destinations for wildlife tourists of national and international origin.

Study findings revealed that the visitors in the RKWS are varied with age, sex, education and occupation. In general male visitors are higher than female visitors in outdoor recreation (Ahmed \& Rahman 1997) and youth groups are more interested in outdoor recreation (Ahmed 1993). In the present study it was found that the young energetic males are very much willing to visit the park The lack of safety, deficiency in proper facilities and the backwardness of women in our society might have discouraged them to come for recreation in this wildlife sanctuary. Educated people are more interested to visit the RKWS. The results also revealed that education can play a vital role in determining the demand for recreational activities at the RKWS. Considering occupation students can play the leading role to gear up the recreational activities in the RKWS Ahmed (1993) also repeated that students are the major groups of outdoor recreation. Another work done by Ahmed \& Rahman (1997) also showed that participation of outdoor recreation increase with increasing educational level but decreases after higher secondary level. The results also predict that RKWS might be a good recreational area for enjoying with family members and group of friends. Visitors were also asked to find out amount of money they spend or willing to pay for the recreation they get into the RKWS. From economic point of view the study area is major source of recreation for medium class people. Bangladesh is a developing country and a large percentage of people belong to the medium class for whose protected area is an important area for recreation. Generally we know mass gathering of people is seen in any recreational areas during holidays. This is not exceptional in context of our country. In RKWS it reflects that more visit followed less recreational demand and vice versa. Most of the recreationalist wished to stay inside the park for two to five hours only. Most of the visitors come from other district and also from the city area.

The RKWS comprises the remaining natural forests, and the plantations raised earlier by converting high forests of great biodiversity value. Large deciduous trees are mixed with evergreen smaller trees and bamboos. The top canopy includes Artocarpus chaplasha, Dipterocarpus turbinatus, Elaeocarpus floribundas, Dillenia pentagyna, Castanopsis tribuloides, etc. A total of 167 species (mammals, birds, reptiles and amphibians) including forest-dwelling and wetland-associated species were documented. Besides this Tipra polli, tea garden creates more interest for visitors (Ali 2008). The field observation and the study on the visitors revealed that recreational facilities like wildlife, natural beauty and tribal community attract the visitors. This finding corresponds with the opinion of Ceballos-Lascurain (1993) that green spaces with their landscapes, flora and fauna as well as their cultural elements form attractions for tourists. Besides the potentialities the respondents raised the issue of some problems they faced in the park. The similar trend of problems was found in the visitor survey in Sitakunda Botanical Garden and Eco-park of Bangladesh by Nath \& Alauddin (2006), where lack of security measures was the most important issue as visitor's sometimes felled victim to mugging in remote and desolate corners of the WS. Okaka (2007) reported the relatively lower number of visitors to some protected areas of Uganda due to inadequate security situation. Studies on people participation in outdoor recreation found that it revitalizes human sprit, restores people's initiatives of life, produces feeling of well-being, satisfaction, creativeness and physical conditions (Wenger 1984, Brockman \& Merriam 1979, Douglas 1982, Torkildsen 1992, Jashimuddin et al. 2004, Jashimuddin \& Alamgir 2005). So, from this study it can be concluded that RKWS might be a potential outdoor recreation area.

\section{Conclusion and recommendations for planners and managers}

Tourism in RKWS is a very new development. In order to develop this sector further, separate management plan and an action plan for tourism should be developed. Numerous people come to RKWS to see forests, wild life, and natural beauty and to visit the surrounding attractions. The park has a good potentiality for eco-tourism even though it does not offer any lodging facilities. Bangladesh government can create opportunities to develop the tourist industry (ecotourism) based on protected areas. Tourism as a wildlife and forest conservation and sustainable development tool can be promoted and from a community perspective it is expected to provide benefits that ultimately enhance local support for the conservation of natural resources. The result of the study did not reveal negative attitude about tourism development at RKWS but pattern of attitude involving tourism may change in the future as tourism develops. Therefore, further studies will be needed in the future to gather quantitative data on the performance of tourism at the protected areas in terms of ecological, socio economic and community conservation levels.

\section{References}

Ahmed MR (1993). Outdoor recreation potentials of foy's lake area, Chittagong. Bangladesh Journal of Forest Science 22 (2): 30-36.

Ahmed MR, Rahman MM (1997). Visitor's participation in outdoor recreation activities Bhawal national park with respect to some socio economic variables. Bangladesh Journal of Forest Science 26 (1): 37-42.

Ali D (2008). Present status and tourism potentiality of Sylhet forest division, Bangladesh. B.Sc. (Hons.) Project paper, Department of Forestry, Shahjalal University of Science and Technology, Sylhet, Bangladesh, pp. 1- 55.

Borrie WT, McCool SF, Stankey GH (1998). Protected area planning principles and strategies. John Wiley and Sons Ltd, UK.

Brockman FC, Merriam LC (1979). Recreational use of wild lands. McGraw Hill, New York, USA, pp. 337.

Butler WR, Boyd WS (2000). Tourism and national parks: a long but uneasy relationship. In: "Tourism and national parks: issues and implications" (Butler WR, Boyd WS eds). John Wiley \& Sons Ltd., UK, pp. 70-75.

Ceballos-Lascurain H (1993). Ecotourism as a worldwide phenomenon. In: "Ecotourism: a guide for planners and managers" (Lindberg K, Hawkins DE eds), Natraj Publishers, Dehradun, India, pp. 80-83.

Chape S, Blyth S, Fish L, Spalding M (2003). United nations list of protected areas. IUCN, Gland, Switzerland and UNEP-WCMC, Cambridge, UK, pp. 44.

Douglas WR (1982). Forest recreation. Pergamon Press, New York, USA, pp. 354.

Drumm A, Moore A (2005). Ecotourism development: a manual for conservation planners and managers. Volume I: An Introduction to Ecotourism Planning. The Nature Conservancy, Washington, DC, pp.31-42.

Fiallo EA, Jacabson SK (1995). Local communities and protected areas: attitudes of rural residents towards conservation and Machalilla national park, Ecuador. Environmental Conservation 
22 (3): 241-249. - doi: 10.1017/S0376892900010 $64 \mathrm{X}$

Ghimire BK, Pimbert MP (1997). Social change and conservation: an overview of issues and concepts. In: "Social change and conservation" (Krishna PG, Michel PP eds). Earthscan Publications Limited, London, UK, pp. 1-45.

GOI (1994). Government of India. National Tiger action plan. Ministry of Environment and Forests, Government of India, New Delhi, India.

Goodwin H (1996). In pursuit of ecotourism. Biodiversity \& Conservation 5 (3): 277-292. doi: 10.1007/BF00051774

Hales D (1989). Changing concepts of national parks. In: "Conservation for the Twenty-First Century" (Western D, Pearl M eds). Oxford University Press, London, UK, pp. 139-144.

Hannah L (1992). African people, African parks: an evaluation of development initiatives as a means of improving protected area conservation in Africa. USAID, Biodiversity Support Program, Conservation International, Washington, USA.

He G, Chen X, Liu W, Bearer S, Zhou S, Cheng LY, Zhang H, Ouyang Z, Liu J (2008). Distribution of economic benefits from ecotourism: a case study of wolong nature reserve for giant Pandas in China. Environmental Management 42: 1017-1025. - doi: 10.1007/s00267-008-92143

Ite UE (1996). Community perceptions of the Cross River national park, Nigeria. Environmental Conservation 23 (4): 351-357. - doi: 10.1017/ S0376892900039217

Jashimuddin M, Alamgir M (2005). Visitors of urban green space based recreation: a case study from Chittagong Metropolitan Area: the Chittagong University. Journal of Science 29 (2): $45-$ 52.

Jashimuddin M, Alamgir M, Majumder R, Patwari MRA, Bhuiyan MAR (2004). Potentials visitors of Mirpur zoological garden as an outdoor recreation area of Dhaka, Bangladesh. Pakistan Journal of Biological Science 7(9): 1509-1512. - doi: 10.3923/pjbs.2004.1509.1512

Landell-Mills N, Porras IT (2002). Silver bullet or fools' gold? A global review of markets for forest environmental services and their impact on the poor. International Institute for Environment and Development, London, UK, pp. 254.

Lindberg K, Enriquez J (1994). An analysis of ecotourism's economic contribution to conservation and development in Belize. WWF/Ministry of Tourism and Environment, Belize City, Belize, pp. 105.

Mehta JN, Kellert SR (1998). Local attitudes towards community-based conservation policy and programmers in Nepal: a case study of the Makalu-Barun conservation area. Environmental Conservation 25 (4): 320-333. - doi: 10.1017/ S037689299800040X

NACOM (2003). Site level appraisal for protected area co-management, Rema-Kalenga wildlife Sanctuary. Nature conservation management. International Resources Group, Dhaka press, Bangladesh.

Nath TK, Alauddin M (2006). Sitakunda botanical garden and eco-park, Chittagong, Bangladesh: its impacts on rural community. International Journal of Biodiversity Science and Management 2 (1): 1-11.

Nishat A, Huq S, Imamul M, Barua S, Reza P, Ali AHM, Khan MAS (2002). Bio-ecological zones of Bangladesh. IUCN, Bangladesh.

NSP (2006). Protected areas of Bangladesh: A visitor's guide. Nishorgo Support Project, Dhaka, Bangladesh, pp. 41

Okaka W (2007). The role of media communications in developing tourism policy and cross cultural communication for peace, security for sustainable tourism industry in Africa. In: Proceedings of the $4^{\text {th }}$ International Institute of Peace through Tourism (IIPT), African Conference on Peace through Tourism at Educators' Forum, Kampala (Uganda) 19-22 May 2007.

Rao K (1996). Management problems: people in protected areas. In: Proceedings of the "SAARC Workshop on Wildlife Management". Dehradun,
India.

Sekhar NU (2003). Local people's attitudes towards conservation and wildlife tourism around Sariska Tiger Reserve, India. Journal of Environmental Management 69: 339-347. - doi: 10.1016/ j.jenvman.2003.09.002

Sharma R, DeCosse P, Khan M, Mazumder A (2005). Co-Management of protected areas in South Asia with special reference to Bangladesh. Nishorgo Support Project, Dhaka, Bangladesh, pp. 16.

Torkildsen G (1992). Leisure and recreation management. E and FN Spon, London, UK, pp. 463. Uddin MZ (2002). Exploration, documentation and germplasm collection of plant genetic resources of Rema-Kalenga Wildlife Sanctuary (Habigong) in Bangladesh, Ph. D. Thesis, University of Dhaka, Bangladesh.

Vantomme P, Markkula A, Leslie RN (2002). Non-wood forest products in 15 countries of tropical Asia: a regional and national overview. FAO-RAP, Bangkok, Thailandia, pp. 15-24.

Walpole MJ, Goodwin HJ (2000). Local economic impacts of dragon tourism in Indonesia. Annals of Tourism Research 27: 559-576. - doi: 10.1016/S0160-7383(99)00088-2

Walpole MJ, Goodwin HJ, Ward KGR (2001). Pricing policy for tourism in protected areas: lessons from Komodo National Park, Indonesia. Conservation Biology 15: 177-185. [online] URL: http://www.jstor.org/stable/2641660

Wells M, Brandon K, Hannah L (1992). People and Parks: linking protected area management with local communities. World Bank, Washington, DC, USA.

Wenger KF (1984). Forestry handbook. John Wiley and Sons, New York, USA.

Western D, Wright M (1994). Natural connections: perspectives in community-based conservation. Island Press, Washington, DC, USA.

Williams PW (1992). A local framework for ecotourism development. Western Wildlands 18 (3): 14-19. 